\title{
SHARING POWERS WITHIN EXCLUSIVE COMPETENCES: RETHINKING EU ANTITRUST LAW ENFORCEMENT
}

\author{
Pieter Van Cleynenbreugel
}

\begin{abstract}
Summary: Although the establishment of competition rules forms part of the EU's exclusive competences, the application and enforcement of those rules has always been shared consistently between the EU and its Member States.

The sharing of enforcement powers is conceptualised traditionally as a delegation of the exercise of exclusively conferred competences. The Court of Justice of the European Union's case law in the context of EU antitrust law enforcement nevertheless raises profound questions as to the overall tenability of this delegation framework in this particular field of EU exclusive competence.
\end{abstract}

This contribution argues the traditional exclusive competences narrative indeed fails to grasp the system of shared enforcement powers underlying EU antitrust law. Seeking to make sense of the realities of that system in light of EU competence doctrines, it explores the constitutionality of legal policy strategies enabling a more explicit recognition of shared competences principles as an inherent part of this EU exclusive competence domain.

\section{Introduction}

Following the entry into force of the Lisbon Treaty, article 3(1)(b) TFEU explicitly ranks the establishment of competition rules necessary for the functioning of the internal market among the European Union's exclusive competences. ${ }^{1}$ In practice, however, and comparable to other domains of EU exclusive competences, the enforcement of those rules had already been shared consistently between supranational and Member State actors. ${ }^{2}$ The de facto shared nature of EU and Member States'

\footnotetext{
Associate professor (chargé de cours) of European Union law, Université de Liège, Belgium. PhD (KU Leuven); LLM. (Harvard), pieter.vancleynenbreugel@ulg.ac.be. I am grateful to the participants in the $14^{\text {th }}$ Jean Monnet Seminar organised by the University of Zagreb on 'Rethinking competences' and the anonymous reviewers for comments and suggestions. The usual disclaimer applies.

1 See for a general introductory overview of this matter, G Monti, 'Legislative and Executive Competences in Competition Law' in L Azoulai (ed), The Question of Competence in the European Union (OUP 2014).

2 See art 89 EEC, referring to the role of Member States and Member State authorities in this respect; Council Regulation 17 implementing Articles 85 and 86 of the Treaty [1962]
} 
enforcement powers is not as such incompatible with the idea of exclusive competences. ${ }^{3}$ According to the traditional, so-called dual federalism interpretation of $\mathrm{EU}$ exclusive competences, the implementation of those competences can be delegated to Member States as long as the EU exclusively determines the terms of such delegation. By virtue of secondary legislation in the realm of antitrust and State aid law, national competition authorities and national courts can effectively be called upon to join the effort of enforcing the EU competition law prohibitions, supported by diversified European Commission 'help lines'. ${ }^{4}$

In its case law, the Court of Justice has not followed consistently the strict dual federalism logic that seems to underlie the secondary legislation structuring EU antitrust law enforcement. ${ }^{5}$ Although judgments on the existence of enforcement powers do indeed leave no or virtually no room for Member States beyond the tasks explicitly delegated to them by virtue of secondary legislation (eg the Court's 2011 judgment in Tele 2 Polska), the Court's assessments of the actual exercise of those powers by national courts or authorities (most notably the Court's 2012 Expedia, 2013 Allianz Hungaria and 2015 Maxima Latvija judgments) and of the role of those courts and authorities in the absence of specifically conferred or harmonised enforcement powers within the framework of EU secondary legislation (the 2010 Vebic, 2011 Pfleiderer and 2016 Eturas judgments) have followed increasingly a rather different approach. In the latter cases, the Court appears implicitly to have replicated or at least presumed applicable a competence pre-emption framework commonly deemed relevant only in the realm of 'shared' EU-Member State competences.

OJ L13/204 (English Special Edition, Chapter 1959-1962, 87) envisaged some cooperative features as well. For a cursory overview, see Grant Kelleher, 'The Common Market Antitrust Laws: The First Ten Years' (1967) 12 Antitrust Bulletin 1219.

3 On the necessary reality of shared implementation and enforcement of rules falling within the ambit of EU exclusive competences, see in general, Udo Di Fabio, 'Some Remarks on the Allocation of Competences between the European Union and its Member States (2002) 39 CML Rev 1289, 1298.

4 On those help lines, recently, see Pieter Van Cleynenbreugel, 'National Courts and EU Competition Law: Lost in Multilevel Confusion?' in Nada Bodiroga-Vukobrat, Sinisa Rodin and Gerald Sander (eds), New Europe - Old Values? Reform and Perseverance (Springer 2016).

5 Antitrust law generally encompasses those branches of EU competition law that prohibit certain kinds of anticompetitive agreements or unilateral behaviour. In EU law, art 101 TFEU (prohibition of collusive behaviour by two or more undertakings or an association of undertakings) and art 102 TFEU (prohibtion of abusive behaviour by an undertaking occupying a dominant economic position in a relevant market) are considered the antitrust branches of EU competition law <http://ec.europa.eu/competition/antitrust/overview_en.html> accessed 10 December 2016. Other branches, such as ex ante concentration control, State Aid and Services of General Economic Interest, also form part of EU competition law; those branches do have different features, however, also in the realm of law enforcement. This contribution essentially focuses on the antitrust branches and their enforcement as structured by the European Union. 
This contribution argues that the traditional dual federalism narrative accompanying exclusive competences fails to grasp the realities of shared enforcement powers underlying EU antitrust law. Establishing that claim, the second section will document to what extent principles of shared competences have governed more or less implicitly the enforcement of exclusive competences in the realm of EU antitrust law. Particular attention will be devoted to the shared enforcement powers regime and the case law on the existence and actual exercise of enforcement powers within or beyond the framework established by Council Regulation $1 / 2003 .{ }^{6}$ On the basis of an overview of recent case law, it will be submitted that EU constitutional principles enabling the pre-emption of national rule interpretation or enforcement choices can, albeit with some caution, be recognised implicitly within the case law structuring the existing antitrust law enforcement framework. Seeking to make sense of those pre-emption realities in light of EU constitutional law competence doctrines, the third section proposes a more explicit recognition of shared competences principles in this particular field of EU law. Recognising those principles more explicitly, it will be submitted, may result in more clarity regarding the powers of national enforcement authorities and courts in their application of EU antitrust law.

It has long been acknowledged that exclusive competences are never completely exclusively retained at the EU level. ${ }^{7}$ The same also goes for the EU's competition law competences. ${ }^{8}$ The aim of this paper is not to contest that finding, but rather to build upon it by looking for a constructive and constitutionally coherent way to acknowledge, define and structure the realities of shared enforcement powers in the realm of EU antitrust law enforcement. Beyond the particular realm of antitrust law, the proposed solutions offered here could also contribute to discussions on similar problems in other domains of EU exclusive competences. This may eventually result in more clarity on the scope and limits of integrating shared competences principles in the framework of EU exclusive competences and, more generally, in a better comprehension of the exact place and role of exclusive competences within the EU constitutional framework.

\footnotetext{
6 Council Regulation 1/2003 of 16 December 2002 on the implementation of the rules on competition laid down in Articles 81 and 82 of the Treaty [2003] OJ L1/1 (hereinafter referred to as Regulation 1/2003).

7 See, among others, George Bermann, 'Competences of the Union' in Takis Tridimas and Paolisa Nebbia (eds), European Union Law for the Twenty-First Century. Rethinking the New Legal Order Volume I Constitutional and Public Law External Relations (Hart 2004) 66.

8 See for an overview preceding the entry into force of Regulation 1/2003, Emil Paulis, 'Coherent Application of EC Competition Rules in a System of Parallel Competencies' in Claus-Dieter Ehlermann and Isabella Atanasiu (eds), European Competition Law Annual 2000: The Modernization of EC Antitrust Policy (Hart 2001) 408.
} 


\section{Exclusive competence through shared enforcement? EU antitrust law and dual federalism}

The EU's principled recognition of exclusive competences results from a classical understanding of dual federalism, in which mutually exclusive spheres of competences govern different fields of societal regulation. Only through explicit or implicit delegations can one sphere intervene in the other sphere. Such intervention is always subject to the terms of the delegation, which can be revoked by the delegating authority. This system of dual federalism can equally be found to structure the EU antitrust law enforcement framework established by Regulation 1/2003, which consistently relied on mutual cooperation, rather than exclusively separated competence spheres (2.1).

According to the system set up by Regulation 1/2003, national competition authorities and courts have to apply articles 101 and 102 TFEU prohibitions on collusive behaviour and on the abuse of a dominant economic position - to their full extent and apply those provisions to highly divergent factual situations. At the same time, the Regulation limits the powers granted to those authorities and courts, in an attempt to ensure coherence in the application and interpretation of those Treaty provisions. Whilst this shared enforcement system reflects a delegation of exclusive competences to Member State actors within a domain of EU exclusive competence, the Court's case law on the application and interpretation of articles 101 and 102 TFEU has had to work its way around practical enforcement difficulties generated by such a delegation approach. This section submits that the traditional delegation approach indeed fails to explain and structure the actual exercise of those powers in cases before national authorities and courts, as the Court's recent case law appears to confirm ever more explicitly (2.2). As a result, the delegation approach no longer sufficiently covers the realities of shared antitrust enforcement shaped by the Court of Justice (2.3).

\subsection{The classical interpretation of exclusive competences and dual federalism}

The relationship between exclusive competences and dual federalism has been well documented in recent EU law scholarship. ${ }^{9}$ Nothing would suggest that the constitutional principles underlying exclusive competences would not apply in relation to EU competition law in general and EU antitrust law (articles 101 and 102 TFEU) in particular. This section briefly revisits the dual federalism-exclusivity framework (2.1.1)

\footnotetext{
$9 \quad$ For a full overview, see Robert Schütze, From Dual to Cooperative Federalism. The Changing Structure of EU Law (OUP 2009) and the references included therein.
} 
and applies it to the enforcement regime set out by the above-mentioned Regulation (2.1.2).

\subsubsection{EU dual federalism in theory}

In its pioneering case law on the scope and nature of competences of the European Economic Community, the Court of Justice gradually recognised the existence of competences exclusively conferred on the European Union. ${ }^{10}$ Exclusive competences represented a small sample of conferred competences that - given their nature - precluded any Member State intervention. ${ }^{11}$ The Court identified the conservation of marine biological resources under the common fisheries policy ${ }^{12}$ and the development of a common commercial policy ${ }^{13}$ to be exclusively supranational. In addition, competences to conclude international agreements could equally fall within the then-Community's exclusive competences. This was particularly the case if any steps taken outside the Community legal framework were incompatible with the unity of the Common Market and the uniform application of Community law. ${ }^{14}$ The categories of exclusive competences were given explicit Treaty recognition in the ill-fated Treaty establishing a Constitution for Europe ${ }^{15}$ and in the Lisbon Treaty. ${ }^{16}$ In addition, those Treaties also included, for the first time, EU competition law and monetary policy amongst the exclusively conferred competences. ${ }^{17}$

In its case law on exclusive competences, the Court maintained that, within a specific area of exclusive competences, Member States lose all

\footnotetext{
10 Armin Von Bogdandy and Jürgen Bast, 'The European Union's Vertical Order of Competences: The Current Law and Proposals for its Reform' (2002) 39 CML Rev 227, 241-242.

11 Koen Lenaerts, 'Regulating the Regulatory Process: "Delegation of Powers" in the European Community', (1994) 18 EL Rev 23, 30; Robert Schütze, 'Dual Federalism Constitutionalised: The Emergence of Exclusive Competences in the EC Legal Order' (2007) 32 EL Rev 1,6 .

12 Opinion 1/75 [1975] ECR 1355; Case 41/76 Donckerwolcke [1976] ECR 1921, paras 3135; Opinion 1/78, [1979] ECR 2871, para 44-45; Opinion 2/91, [1993] ECR I-1061, para 8; Opinion 1/94 [1994] ECR I-5267, para XIII; Case C-347/03 Regione autonoma FriuliVenezia Giulia [2005] ECR I-3785, para 75.

13 Case 3/76, 4/76 and 6/76 Kramer [1967] ECR 1279, paras 39-41; Case 804/79 Commission v United Kingdom [1981] ECR 1045, paras 17-18; Opinion 2/91, para 8; C-25/94 Commission v Council [1996] ECR I-1469, para 40.

14 See among other cases, Case 22/70 Commission v Council (AETR) [1971] ECR 263, para 28-31. See also Opinion 1/76, [1977] ECR 741 para 5. For a nuanced overview of constitutional problems in that regard, see Geert De Baere, Constitutional Principles of EU External Relations (OUP 2008) 43-51.

15 Art I-12 (1) of the Treaty establishing a Constitution for Europe: When the Constitution confers on the Union exclusive competence in a specific area, only the Union may legislate and adopt legally binding acts, the Member States being able to do so themselves only if so empowered by the Union or for the implementation of Union acts; the list of competences could be found in arts I- 13 .

16 Arts 2(1) and 3 TFEU.

17 See art 3(1)(b) and (c) TFEU.
} 
powers to lay down rules. The boundaries of that area of exclusivity were to be determined by the Court itself, having the final authority over the interpretation of EU law. As a result, a system of dual federalism came about, in which the EU and Member States operated each within the boundaries of their own competences. ${ }^{18}$

At the same time, two EU constitutional law features have limited the complete detachment of EU and Member States' competences within domains of exclusivity.

Firstly, it has been argued that the scope of any EU exclusive competence generally remained limited to instances where interstate trade would be affected in the absence of supranational intervention. ${ }^{19}$ Member States could theoretically regulate matters that would not affect interstate trade, although they would have to justify the absence of such interstate effects. Given the transnational dimensions of the specific areas of exclusive competence, such attempts are not likely to be successful, as the scope of EU law could easily extend to situations that appear to be wholly internal to one Member State. ${ }^{20}$ In addition, it has to be acknowledged that the actual exclusive competences identified all relate to commerce-oriented fields, which may justify why this condition can be extracted from the case law. Affectation of interstate trade being a condition determining the applicability of EU law, practices that do not affect such trade in principle fall outside the scope of EU law and therefore do not come within the EU's purview. As such, the absence of effects on inter-state trade still - theoretically - confers regulatory powers on Member States in domains falling within the EU's exclusive competence.

Secondly, the competent EU level has been allowed explicitly or implicitly to delegate the exercise or practical implementation of exclusive competences back to the Member States. As a result, exclusive competences could de facto remain shared in their concrete implementation and execution. A delegation presupposes the grant of exclusive legislative or regulatory authority by the Treaties to the European Union and the subsequent conditional regrant of that authority to the Member States. ${ }^{21}$ National legal systems would in that understanding function

18 See for a judicial example outlining this reasoning, Opinion 1/75, [1975] ECR 1355, paras 11-13.

19 Ronald van Ooik, The European Court of Justice and the Division of Competence in the European Union' in Daniela Obradovic and Nikos Lavranos (eds), Interface between EU Law and National Law (Europa Law Publishing 2007) 15.

20 This would be the case especially in the realm of EU antitrust law, where the effect on the trade criterion has been interpreted rather extensively. For a codification of case law on that matter, see Commission Notice - Guidelines on the Effect on Trade Concept Contained in Articles 81 and 82 of the Treaty [2004] OJ C101/81.

21 Schütze (n 11) 4. See also, Paul Craig, 'Competence: Clarity, Conferral, Containment and Consideration' (2004) 29 EL Rev 328. For a similar interpretation, see K Lenaerts and P Van 
as mere agents of an exclusively competent Union, which powers can be taken away when the EU decides to modify the conditions of delegation. ${ }^{22}$ Whereas such delegation has been criticised for disturbing the balance crafted by EU primary law between the supranational and Member State levels, it has been accepted also as a useful constitutional tool to make the EU competences system work properly. ${ }^{23}$ The Court of Justice has been and will continue to be called upon to assess, on a case-by-case basis, whether or not such delegation is permissible within the realm of a specific EU exclusive competence.With the entry into force of the Lisbon Treaty, article 2(1) TEU added that, within the sphere of exclusive competences, Member States also retain competence to implement Union acts. The added value of this reference to implementing powers remains unclear and most notably raises the so-far unanswered question whether those powers fall within the ambit of what was previously called 'delegation' or whether they add another category to the exclusive competence exceptions. With no case law on the matter, it could be argued that, in the current state of EU law, powers of implementation are one exemple where the EU can delegate powers to the Member States within an exclusive competence sphere.

\subsubsection{Delegating exclusive competences: enforcement-focused dual federalism underlying EU antitrust law}

The classification of EU competition law as an exclusive competence implies that only the European Union institutions can determine a European competition policy and shape legal provisions enabling it. ${ }^{24}$ The 'exclusivity' of EU competition competences in principle also includes the primary competence to supervise, apply and enforce the EU competition law provisions.$^{25}$ Article 105 TFEU confirms this feature, by stating that the Commission shall ensure the application of the principles laid down in articles 101 and 102, albeit in cooperation with the competent authorities in the Member States, which shall give it their assistance. As already implied in this Treaty provision, delegation of competences to the Member States is clearly posited as a constitutional possibility in this domain of EU exclusive competence. Enforcement Regulations 1/2003 in the realm of antitrust law and 2015/1589 in the realm of State aid could be considered to have delegated such powers, to a more or less limited ex-

\footnotetext{
Nuffel, Constitutional Law of the European Union (Robert Bray \& Nathan Cambien, eds, $2^{\text {nd }}$ edition, Sweet \& Maxwell 2011) 126.

${ }^{22}$ On Member States' agency roles especially in the realm of EU telecommunications law, see also Maartje De Visser, Network-Based Governance in EC Law. The Example of EC Competition and EC Telecommunications Law (Wolf Legal Publishers 2008) 68-70.

${ }^{23}$ Schütze (n 9) 174-175.

24 As this lies within the EU's 'area of exclusivity', see van Ooik (n 19) 15.

25 See art 105(1) TFEU.
} 
tent, to national courts and - in the realm of EU antitrust law - national authorities. $^{26}$

Regulation 1/2003 reflects the dual federalism nature of EU antitrust law exclusive competences. ${ }^{27}$ On the one hand, it is premised on a seemingly clear distinction between EU and national competition law provisions. Both sets of provisions belong to two different spheres of competences; national authorities can apply national antitrust law provisions, the European Commission EU competition law provisions. On the other hand, they equally confirm that national authorities can act, in circumstances determined by EU law itself, as agents of the European Commission when they are applying EU antitrust law provisions, thus limiting the autonomy of Member States' authorities in this respect.

The first limb - an exclusive area of competence - has been confirmed explicitly by the Court of Justice. In its 2013 Toshiba judgment, the Court of Justice confirmed this position, albeit implicitly. The case concerned the application and extent of the principle of ne bis in idem as a matter of EU law in general and EU competition law in particular. ${ }^{28}$ Specific questions revolved around whether or not a national competition authority was able to prosecute and fine an undertaking on the basis of its national competition law, even though the same behaviour had already been the subject of a Commission inquiry. ${ }^{29}$ The case was all the more relevant since the Czech national competition authority in that case relied on its national competition law to prosecute behaviour preceding the accession of the Czech Republic to the European Union. ${ }^{30}$ In its judgment, the Court most famously hinted at the existence of a specific ne bis in idem principle in EU antitrust law. ${ }^{31}$ At the same time, however, it also confirmed the dual federalism nature of EU antitrust law enforcement, confirming that EU and national antitrust law provisions belong to two different spheres of competence. The Court specifically stated that Regulation 1/2003 does not imply that the opening of a proceeding by the Commission permanently and definitively removes the national com-

\footnotetext{
26 For the State aid framework, see Council Regulation (EU) 2015/1589 of 13 July 2015 laying down detailed rules for the application of Article 108 of the Treaty on the Functioning of the European Union [2015] OJ L248/9.

27 James Venit, 'Brave New World: The Modernization and Decentralization of Enforcement under Articles 81 and 82 of the EC Treaty' (2003) 40 CML Rev 545, 555; Katarina Pijetlovic, 'Reform of EC Antitrust Enforcement: Criticism of the New System Is Highly Exaggerated' (2004) 25 ECLR 356, 357.

28 On this judgment in detail, see Wouter Devroe, 'How General Should General Principles Be? Ne Bis in Idem in EU Competition Law' in Ulf Bernitz, Xavier Groussot and Felix Shulyok (eds), General Principles of EU Law and European Private Law (Kluwer 2013).

29 Case C-17/10 Toshiba Corporation and Others [2012] ECR I-0000, para 29.

30 Case C-17/10 Toshiba Corporation and Others, Opinion of Advocate General Kokott, para 3.

31 Case C-17/10 Toshiba Corporation and Others, para 79.
} 
petition authorities' power to apply national antitrust law when EU law does not govern a particular factual setting. ${ }^{32}$ Within its own scope of application, national antitrust law therefore remains relevant and readily applicable.

In its January 2016 DHL Express judgment, the Court also confirmed this position in relation to leniency submission procedures at EU and Member State levels. ${ }^{33}$ Again, the Court acknowledged that EU and national leniency procedures serve different objectives and therefore can be applied separately and in parallel. They thus belong to different areas of competences at either EU or Member State level.

At the same time, Regulation 1/2003 also envisages the partial integration of national authorities and courts in the EU's envisaged enforcement system. Those features of the Regulation seemingly fit the second limb of dual federalism theory - a delegation of powers to national authorities and courts. In that regard, article 3 imposes a duty on national competition law authorities to apply EU competition law in cases that affect trade between Member States. ${ }^{34}$ Member States can also continue to apply their national antitrust law provisions in parallel with the EU provisions, yet the application of those national competition law provisions may not lead to the prohibition of agreements which may affect trade between Member States but which do not restrict competition within the meaning of article 101(1) of the Treaty or which fulfil the conditions of article 101(3), or which are covered by a block exemption regulation. ${ }^{35}$ In practice, this means that what EU law deems legal cannot subsequently be deemed illegal under Member States' antitrust laws. At the same time, however, Member States shall not be precluded from adopting and applying on their territory stricter national laws which prohibit or sanction unilateral conduct engaged in by undertakings. In that situation, national authorities are granted an explicit authorisation to apply national laws prohibiting behaviour that would be deemed legal under EU law.

According to the dual federalism logic underlying EU exclusive competences, national competition authorities and courts can operate only

32 Case C-17/10, Toshiba Corporation and Others, paras 89-90.

33 Case C-428/14 DHL Express (Italy) Srl and DHL Global Forwarding (Italy) SpA v Autorità Garante della Concorrenza e del mercato [2016] ECR I-0000, para 44.

34 Art 3(1) Regulation 1/2003. On the scope of concurrence from a national law perspective, see Ginevra Bruzzone and Marco Boccaccio, 'Taking Care of Modernization after the Start-Up: A View from a Member State' (2008) 31 World Competition 89.

35 Art 3(2) Regulation 1/2003. See Andreas Klees, 'Breaking the Habits: The German Competition Law after the 7 th Amendment to the Act against Restraints of Competition (GWB)' (2006) 7 German Law Journal 399, 406 on the origins of that rule. Art 3(3) holds that the regime of parallel application does not preclude the application of provisions of national law that predominantly pursue an objective different from that pursued by arts 101 and 102 of the Treaty. Such rules would seem to fall outside the exclusive ambit of EU competition law. 
by virtue of the EU institutions mandating them to do so. The system set up by Regulation 1/2003 does indeed seem to confirm that such a delegation mechanism structures the powers of national authorities and courts within that Regulation. The delegation nature of such competences appears in three different features incorporated within that Regulation.

Firstly, articles 11-13 of Regulation 1/2003 seeks to structure and streamline the national competition authorities' and the European Commission's powers to initiate and terminate investigations and infringement proceedings. Where competition authorities of two or more Member States are aware of the potential existence of restrictive agreements, the fact that one authority is dealing with the case shall be sufficient ground for the others to reject the complaint. The same goes for complaints received in relation to agreements that have already been dealt with by another competition authority. ${ }^{36}$ Any suspension or termination is overseen by the European Commission. The latter may itself terminate or suspend a pending investigation if a national authority has dealt with the case and is considered to be better placed in doing so. ${ }^{37}$ At the same time, article 11(6) of Regulation 1/2003 provides an instrument for the Commission to maintain control over the application of EU competition law. ${ }^{38}$ It states that the initiation by the Commission of supranational investigative procedures shall 'relieve the competition authorities of the Member States of their competence to apply Articles [101] and [102] of the Treaty'. ${ }^{39}$ Theoretically, the Commission could therefore decide to take over a case from a national authority. Article 11(6) nevertheless requires that the national competition authority which will be relieved from duty shall be consulted by the Commission. In practice, the Commission considers article 11(6) to be an ultimate remedy in cases where a national competition authority's position threatens to frustrate the coherent application of EU competition law. ${ }^{40}$

\footnotetext{
36 Art 13(2) of Regulation 1/2003.

37 Art 13 (1) of Regulation 1/2003.

38 This provision does not consider the Commission's deference to national authorities' decisions once the national authority has adopted a decision. A long-standing question in that regard concerned whether or not a national authority's decision applying arts 101 and 102 TFEU is binding on the European Commission. For an early argument in favour of that position, see John Temple Lang, 'European Community Constitutional Law and the Enforcement of Community Antitrust Law' in Barry Hawk (ed), Antitrust in a Global Economy. Annual Proceedings of the Fordham Corporate Law Institute 1993 (Kluwer 1994) 584. The binding scope of national authorities' decisions nevertheless remains problematic and uncertain, again highlighting the Commission's remaining fundamental role as an EU competition law supervisor in that respect.

39 Kris Dekeyser and Maria Jaspers, 'A New Era of ECN Cooperation. Achievements and Challenges with a Special Focus on Work in the Leniency Field' (2007) 30 World Competition 3, 9 refer to this action as the de-seizing of a national authority.

40 Dekeyser and Jaspers (n 39) 9.
} 
Secondly, article 5 of the Regulation limits the scope and scale of decisions to be adopted by national competition authorities when enforcing EU antitrust law. According to that provision, Member States' authorities may, acting on their own initiative or on a complaint, require that an infringement be brought to an end, order interim measures, accept commitments, impose fines, periodic penalty payments or any other penalty provided for in their national law. Where on the basis of the information in their possession the conditions for prohibition are not met, they may likewise decide that there are no grounds for action on their part. In its Tele2 Polska judgment, the Court confirmed, on the basis of a strict interpretation of this provision, that a national competition authority cannot take a decision stating that a practice does not restrict competition within the meaning of article 102 TFEU in a case in which it has found, after conducting proceedings, that the undertaking did not engage in abusive behaviour. ${ }^{41}$ Article 5 offers an exhaustive list of decisions national authorities can adopt when applying EU antitrust law. Only the Commission can adopt a decision finding there has been no infringement of article 102. ${ }^{42}$ Such kinds of decisions have not been delegated to the national authorities and therefore remain with the exclusive competence domain of the competent EU institutions.

Thirdly, the role of national courts is streamlined and extended according to a similar dual federalism logic. According to article 6, national courts shall apply articles 101 and 102 TFEU in their entirety. At the same time, national courts ought to take measures in ensuring the coherence of EU competition law enforcement. In so doing, the courts can rely on both the Court of Justice and the European Commission to ensure that EU competition law does not significantly diverge across different jurisdictions. To that extent, Regulation 1/2003 offers innovative mechanisms aimed at establishing a direct cooperative link between the European Commission and national courts requiring its assistance on competition law matters. Most innovatively, article 15(3) of Regulation $1 / 2003$ provides a right for the Commission to submit written observations to courts of the Member States. With the permission of the court in question, it may also make oral observations. ${ }^{43}$ EU law also grants a similar right to national competition authorities, ${ }^{44}$ any wider powers granted for these authorities under national law notwithstanding. ${ }^{45}$ It follows from those provisions that the Commission or national authorities are allowed

\footnotetext{
41 Case C-375/09 Prezes Urzędu Ochrony Konkurencji i Konsumentów v Tele2 Polska sp. zoo, devenue Netia SA [2011] ECR I-3055, para 27.

42 Case C-375/09 Tele 2 Polska, para 29.

43 Art 15(3) of Regulation 1/2003.

44 Art 15(3) of Regulation 1/2003.

45 Art 15(4) of Regulation 1/2003.
} 
to $^{46}$ intervene in national court proceedings when the coherent application of articles 101 and 102 so requires. ${ }^{47}$ Unlike the authoritative interpretation of EU law by the EU courts, the opinion of the Commission does not legally bind a national court. ${ }^{48}$ The legal effect and practical impact of the opinion on the outcome of a national dispute in practice largely depend on national procedural law. ${ }^{49}$ In order for those administrative actors meaningfully to intervene in Member States judicial proceedings, access to (parts of) the case file is deemed necessary. Regulation 1/2003 therefore provides that the Commission may request the relevant court of the Member State to transmit or ensure the transmission to them of any documents necessary for the assessment of the case. ${ }^{50}$ The transmission of documents can only take place for the purposes of preparing the intervention. ${ }^{51} \mathrm{~A}$ Commission intervention will in principle deal with the economic and legal analysis of the facts underlying the case pending before the national court. ${ }^{52}$

The three above-mentioned features of Regulation 1/2003 summarised here highlight that the system of shared EU antitrust law enforcement has been coined essentially as specific applications of the 'delegation of exclusive competences' framework established within the EU's classical dual federalism framework. The involvement of national courts and authorities is meant to facilitate the coherent implementation of an exclusive field of EU competences, in which the Commission plays a primary role. National authorities and courts have, to a significant extent, been integrated in the Commission-led enforcement system, but remain

\footnotetext{
46 Regulation 1/2003 refers to 'may'. The Commission is not obliged to, but is merely entitled to intervene. As such, it has discretion to intervene in particular instances. See also Kathryn Wright, 'The European Commission's Own "Preliminary Reference Procedure" in Competition Cases' (2010) 16 European Law Journal 736, 744 on the legal nature of the Commission opinion. See also para 19 Commission Notice on the co-operation between the Commission and the courts of the EU Member States in the application of Articles 81 and 82 EC [2004] OJ C101/54 (hereinafter 2004 Courts Notice), which states that '[i]n case the Commission has been contacted by any of the parties in the case pending before the court on issues which are raised before the national court, it will inform the national court thereof, independent of whether these contacts took place before or after the national court's request for co-operation'.

47 Art 15(3) of Regulation 1/2003. Para 322004 Court Notice.

48 Para 29 of the 2004 Courts Notice.

49 Para 9 of the 2004 Courts Notice.

50 In return, art 15(1) of Regulation 1/2003 states that courts of the Member States may ask the Commission to transmit to them information in its possession or its opinion on questions concerning the application of the EU competition rules. In that instance, the national court decides how to treat the Commission's opinion and the value attached to it in compliance with national procedural law. See Wright (n 46) 747 for a contrast with the Amicus opinion in art 15(3) and discussed here.

51 Para 33 of the 2004 Courts Notice.

52 Para 32 of the 2004 Courts Notice. In stating so, the Commission's involvement is extensive compared to the Court's, which can only intervene with regard to legal analysis. See art 267 TFEU and Wright (n 46) 753.
} 
subservient to the Commission, which acts as a primus super pares within this system.

\subsection{Beyond dual federalism delegation in the judicial interpretation of articles 101 and 102 TFEU}

Regulation 1/2003 established a seemingly firm dual federalismoriented enforcement mechanism, in which some powers have been delegated to national authorities, without the Commission losing overall control and authority over EU antitrust enforcement. At the same time, and as a part of the cooperation mechanisms envisaged by Regulation $1 / 2003$, national authorities or courts can be called upon to apply EU competition law without the Commission's direct involvement as a market supervision body in its own right, giving them potentially some liberty in the substantive law interpretation and application of EU antitrust law in cases where the Commission decides not to intervene.

The Court has been confronted with such cases, in which it seemingly deviated from the clear-cut dual federalism system established so far in the context of Regulation 1/2003 and the implementation of the cooperation tools covered by it. The Court's recent case law in the Expedia, Allianz Hungaria and Maxima Latvija judgments confirms this, hinting at a more nuanced approach towards shared EU antitrust enforcement than the dual federalism understanding seems to offer (2.2.1). In addition, case law on the powers of national competition authorities and national courts in fields that have not or not entirely been covered by Regulation 1/2003 also hints at a similar deviation from the classical dual federalism logic sketched in the previous section. The judgments in Vebic, Pfleiderer and Eturas are most instructive in this respect (2.2.2).

\subsection{1 'Substantive law' autonomy?}

Expedia presented the Court with the first opportunity to consider the role of national competition authorities within the enforcement system of Regulation 1/2003. In the case at hand, the French competition authority decided to commence infringement proceedings against an agreement between Expedia and the French Railways which had as its object to limit competition in on-line travel agency services. The question raised was whether the national authority could consider this agreement to be prohibited on the basis of article 101(1) TFEU, now that such an agreement would likely benefit from so-called de minimis exceptions established by the European Commission. According to such exceptions, the Commission committed itself not to prosecute matters that did not have a sufficiently appreciable effect on competition. ${ }^{53}$ Those exceptions

53 Recital 5, Communication from the Commission - Notice on agreements of minor im- 
being posited in a non-binding Commission guidance document, questions arose regarding their application to national competition authorities. In light of Regulation 1/2003's strict adherence to a dual federalism framework and to maintaining unity and coherence in the application of articles 101 and 102 by national authorities and courts as delegates of the EU institutions, it could have been expected that the Court would rule that those non-binding documents had to be applied by national authorities.

Rather surprisingly, the Court in this case maintained that the de minimis notice does not contain any reference to declarations by the competition authorities of the Member States that they acknowledge the principles set out therein and that they will abide by them. The Court additionally submitted that it did not follow from the objectives of that notice that it is intended to be binding on the competition authorities and the courts of the Member States. ${ }^{54}$ As a result, article 3 of Regulation 1/2003 was to be interpreted as not precluding a national competition authority from applying article 101(1) TFEU to an agreement between undertakings that may affect trade between Member States, but that does not reach the thresholds specified by the Commission in its de minimis notice, provided that that agreement constitutes an appreciable restriction of competition within the meaning of that provision. ${ }^{55}$ As a result, national authorities only have to apply conditions and thresholds read directly into article 101 TFEU by the Court of Justice itself.

The Expedia judgment thus made clear that national competition authorities remain at liberty to make their own assessments on the basis of article 101 TFEU, without necessarily being bound by Commission soft law guidance documents. Through the looking glass of EU constitutional law, such reasoning can also be understood as a confirmation that national authorities and courts remain free to rule independently on the applicability and scope of articles 101 and 102 TFEU, in the absence of binding EU rules on the matter. The implications of such implicit legal reasoning are twofold. On the one hand, it implies that Member States' authorities and courts have to abide by EU legislation, be it of a general or of an individual nature. To the extent that EU secondary law provisions clearly impose a certain kind of procedure or behaviour, those rules have to be followed and the national authorities and courts will act as EU institutions' delegates in this respect. It can be submitted that the same goes for binding decisions adopted by the European Commission in individual cases. To the extent that the Commission considered certain practices

portance which do not appreciably restrict competition under Article 101(1) of the Treaty on the Functioning of the European Union (De Minimis Notice) [2014] OJ C291/1.

${ }_{54}$ Case C-226/11 Expedia Inc v Autorité de la concurrence ea [2012] ECR I-0000, paras 27-30.

55 Expedia (n 54) para 38. 
to be anticompetitive, the same or similar practices investigated by national authorities, even when relating to different undertakings, will have to be deemed anticompetitive as well by those authorities or by national courts, which already follows from article 3(1) of Regulation 1/2003.

On the other hand, however, in the absence of such rules, it can be submitted that national authorities and courts remain at liberty to interpret articles 101(1) and 102 TFEU autonomously in accordance with the basic conditions and requirements. The judgment also shows that the intervention options by the Commission in no way restrain the national judge to come up with an autonomous decision; only in instances where binding decisions have to be invoked will a national judge be called upon to apply those rules of law. In practice, and given the highly factual nature of antitrust cases, this will mean that national authorities and judges will retain their rule-interpretation autonomy to a large extent.

The Court's 2013 judgment in Allianz Hungaria confirmed this interpretation. In that judgment, the Court held that a national authority can consider a set of agreements to be violating article 101 TFEU if, following a concrete and individual examination of the wording and aim of those agreements and of the economic and legal context of which they form a part, it is apparent that they are, by their very nature, injurious to the proper functioning of normal competition on one of the two markets concerned. ${ }^{56}$ To the extent that EU competition law is applicable, the national authority is responsible for making that assessment within those framework conditions. ${ }^{57}$ It is also up to that authority or to a national court to consider the restriction to be one 'by object' or one 'by effect', both of them prohibited by article 101 TFEU but requiring a different analytical toolbox. In Maxima Latvija, the Court further clarified this position, ruling that commercial lease agreements may be considered to be an integral part of an agreement having the 'effect' of preventing, restricting or distorting competition within the meaning of article 101(1) TFEU, from which it is found, after a thorough analysis of the economic and legal context in which the agreements occur and the specificities of the relevant market, that they make an appreciable contribution to the closing-off of that market. ${ }^{58}$ Again, national authorities or courts would have to make that assessment, applying the conditions set out by the Court, but coming to an independent conclusion as to whether those conditions have been fulfilled.

In all the above-mentioned cases, the Court acknowledges that national authorities and/or courts retain some leeway in the absence of

56 Case C-32/11 Allianz Hungária Biztositó Zrt and Others v Gazdasági Versenyhivatal [2013] ECR I-0000, para 51.

57 Allianz Hungária (n 56) para 33.

58 Case C-345/14 SIA Maxima Latvija" v Konkurences padome [2015] ECR I-0000, para 29. 
clear-cut precedent EU law decisions on the specific matter. Although Member States have been delegated the task to apply and interpret EU antitrust law as established by the EU institutions, including the European Commission and the Court of Justice, Regulation 1/2003 also envisaged situations in which no such precedent decisions exist. In those situations, open-ended provisions can in principle be interpreted by national authorities and national courts, although the Commission and Court of Justice retain the final authority over such decisions. In practice, this amounts to situations where national authorities and courts retain autonomous decision-making powers, until the Commission or Court of Justice rules differently. This regime, which in constitutional law terms resembles a framework of 'pre-emption' of Member State level competences (Member States remain competent unless and until supranational law extends to, replaces and contradicts earlier regulations or decisions adopted at Member State level). It follows from this that national authorities and courts can adopt decisions, within the open-textured framework left by articles 101 and 102 TFEU, which could nevertheless be pre-empted by later supranational decisions. Such pre-emption of decisions or powers is in principle inherent to a regime of shared competences rather than exclusive competences. As the case law mentioned here demonstrates, the Court seems to accept this as a reality in EU antitrust law enforcement, especially in instances of substantive law where Regulation 1/2003 did not intervene to regulate EU-Member State interactions.

\subsubsection{Beyond classical dual federalism in the absence of procedural harmonisation}

Even more remarkably, the line of case law grounded in some kind of pre-emption of competences in the realm of the substantive law application and interpretation of EU antitrust law can also be found in relation to procedural issues that have not as such been covered by the provisions of Regulation 1/2003. The judgments in Vebic, Pfleiderer and Eturas confirm this approach.

In Vebic, the Court was asked to interpret article 35(1) of Regulation $1 / 2003$. According to that provision, 'the Member States shall designate the competition authority or authorities responsible for the application of Articles 101 and 102 of the Treaty in such a way that the provisions of this regulation are effectively complied with'. Whilst those authorities may include courts, the Regulation requires that some distinction between prosecuting and decision-making bodies of such a judicial authority are provided for. ${ }^{59}$ The conditions thus imposed seek to ensure that national authorities can effectively fulfil their roles as agents of the European

\footnotetext{
59 Case C-439/08 Vlaamse federatie van verenigingen van Brood- en Banketbakkers, Ijsbereiders en Chocoladebewerkers (VEBIC) VZW [2010] ECR I-12471, para 62.
} 
Union and the implementation of the EU exclusive competences flowing therefrom. In its judgment, the Court ruled that article 35 implies that a national competition authority should be entitled to participate, as a defendant or respondent, in proceedings before a national court which challenge a decision that the authority itself has taken. ${ }^{60}$ As a result, national authorities have to be structured so as to enable the effective implementation of EU antitrust law. At the same time, EU law does not impose specific conditions on the format and functioning of national competition authorities. Quite the contrary, those authorities can continue to function in the absence of more specific binding obligations imposed by the EU legislator, albeit within the confines set out by the Court of Justice through its interpretation of the principles of equivalence and effectiveness.

In Pfleiderer, the Court was asked to rule on whether or not a claimant in a private action for damages caused by anticompetitive behaviour could have access to confession statements filed under a leniency application and held by the national competition authority. The Court stated that the competition authorities of the Member States and their courts or tribunals applying articles 101 and 102 TFEU have to ensure that those provisions are applied in the general interest. ${ }^{61}$ In the absence of binding regulation under European Union law on the subject, it is for Member States to establish and apply national rules on the right of access by persons adversely affected by a cartel, to documents relating to leniency procedures. ${ }^{62}$ The Court went on to state that these national rules cannot however jeopardise the effective application of EU competition law. ${ }^{63}$ The effective application of article 101 TFEU through leniency programmes could be compromised if documents relating to a leniency procedure were disclosed to persons wishing to bring an action for damages, even if the national competition authorities were to grant the applicant for leniency exemption from the fine which they could have imposed. ${ }^{64}$ As a result, a person involved in an infringement of competition law would be deterred to pass on information to public enforcement authorities, ${ }^{65}$ resulting in the diminished attractiveness of leniency programmes overall. At the same time, actions for damages before national courts can make a significant contribution to the maintenance of effective competition in the European Union. ${ }^{66}$ To that extent, it is necessary for a national judge to weigh the respective interests in favour of disclosure of the information

\footnotetext{
VEBIC (n 59) para 64.

Case C-360/09 Pfleiderer AG v Bundeskartellamt [2011] ECR I-5161, para 19.

Pfleiderer (n 61) para 23.

ibid, para 24.

4 ibid, para 26.

65 ibid, para 27.

66 ibid, para 29.
} 
and in favour of the protection of that information provided voluntarily by the applicant for leniency. ${ }^{67}$ Weighing should take place on a caseby-case basis, taking into account all the relevant factors of the case. ${ }^{68}$ EU law does not as such preclude a person who has been adversely affected by an infringement of EU competition law and is seeking to obtain damages from being granted access to documents relating to a leniency procedure involving the perpetrator of that infringement. However, it is for the courts and tribunals of the Member States, on the basis of their national law, to determine the conditions under which such access must be permitted or refused by weighing the interests protected by EU law. ${ }^{69}$

In those circumstances, national courts effectively have to balance whether or not access should be granted. As the Court held subsequently in Donau Chemie, EU law not only permits such balance in the absence of binding EU rules, it also pre-empts Member States from maintaining legislative provisions that limit such balancing. ${ }^{70}$ The system set up by this case law confirms the pre-emption approach. Member States can keep balancing mechanisms in existence, but cannot as such restrict any such balancing that would go against the framework established by the Court of Justice. Only binding procedural rules at the EU level would be able to restrict such balancing. In Directive 2014/104/EU, which is currently being transposed, limits to such balancing have indeed been imposed as a matter of EU law. ${ }^{71}$ Prior to the adoption of those rules, national judges were entirely free to complete autonomous balancing assessments. ${ }^{72}$

Eturas presents the latest confirmation of a similar pre-emption approach. The case concerned a Lithuanian online platform for travel agents, through which messages regarding pricing policies were distributed, which were subsequently incorporated in the technical algorithms

\footnotetext{
67 ibid, para 30.

68 ibid, para 31.

69 ibid, para 32. The German judge refused access to the requested documents in the national case. See Amtsgericht Bonn, Pfleiderer/Bundeskartellamt, judgment of 18 January 2012, 51 Gs 53/09 AG Bonn.

70 Case C-536/11 Donau Chemie [2013] ECR I-0000, para 35. For more reflections on disclosure of documents induced by national judges, see Elsbeth Beumer and Agis Karpetas, 'The Disclosure of Files and Documents in EU Cartel Cases: Fairytale or Reality?' (2012) 8 European Competition Journal 123, 129-130.

71 Art 6(6) of Directive 2014/104/EU of the European Parliament and of the Council of 26 November 2014 on certain rules governing actions for damages under national law for infringements of the competition law provisions of the Member States and of the European Union [2014] OJ L349/1.

72 See on that shift, Pieter Van Cleynenbreugel, 'Embedding Procedural Autonomy: The Directive and National Procedural Rules' in Maria Bergström, Marios Iacovides and Magnus Strand (eds), Harmonising EU Competition Litigation. The New Directive and Beyond (Hart 2016) 113-115.
} 
governing the platform's functioning. ${ }^{73}$ Although the case includes many other novelties relating to online platforms and EU antitrust law, ${ }^{74}$ the Court equally clarified the roles of national authorities in the absence of more specific binding procedural rules. It held that it remains for the national court to examine - on the basis of the national rules governing the assessment of evidence and the standard of proof - whether, in view of all the circumstances before it, the dispatch of a message, such as that at issue in the main proceedings, may constitute sufficient evidence to establish that the addressees of that message were aware of its content. ${ }^{75}$ At the same time, the Court explicitly acknowledged that the presumption of innocence precludes the referring court from considering that the mere dispatch of that message constitutes sufficient evidence to establish that its addressees ought to have been aware of its content. In doing so, the Court established a limit within which Member States' interpretative autonomy can be exercised safely. Once again, it can be inferred from this judgment that Member States' authorities and courts remain at liberty to organise evidence procedures, albeit within some limits set at the EU level. Those limits effectively prevent Member States from taking independent action. Beyond those limits, however, national procedural and enforcement competences remain fully in existence.

All the cases touched upon here demonstrate again that, in the absence of binding procedural rules imposing clear obligations on Member States' authorities and courts as a matter of EU law, those authorities and courts remain at liberty to apply national law rules or their own assessment schemes. They will only be pre-empted from doing so if EU law imposes additional conditions or to the extent that new binding procedural rules are being adopted at the EU level. Again, it would seem that principles of pre-emption - traditionally at stake only in relation to shared competences spheres - are functioning against the background of the implementation of EU antitrust enforcement, embedded within the EU's exclusive competences.

\subsubsection{A brief comparison of both strands of case law}

It appears from the previous section that Regulation 1/2003 established, at least in some respects, a classical dual federalism enforcement system, on the basis of which national authorities and courts are being considered agents or delegates of the EU institutions whenever they are required to apply EU antitrust law. Clear obligations imposed on them and additional intervention opportunities granted to the European Com-

\footnotetext{
73 Case C-74/14 'Eturas' UAB and Others $v$ Lietuvos Respublikos konkurencijos taryba [2016] ECR I-0000, para 6-11.

74 ibid, para 43.

75 ibid, para 33.
} 
mission seem to indicate that national authorities and courts cannot exercise EU antitrust enforcement competences in a truly autonomous way. The Court's interpretation of the mechanisms thus outlined in Regulation 1/2003 also confirms that position.

At the same time, however, in the absence of a specific procedural harmonisation mechanism or in the substantive law determination and resolution of a specific case, it is clear that Member States' authorities and courts retain significant decision-making autonomy, which will only be pre-empted by future contrary interpretations by the Court of Justice or the Commission. As a result, in those instances, principles governing the pre-emption of Member States' competences appear to underlie the Court's case law, despite EU competition law being an exclusive competence, in which case pre-emption is considered not to be at issue.

The question can therefore legitimately be raised whether more explicit recognition of EU pre-emption principles applicable in relation to shared competences can be used to structure, limit and enable the system that seems to be underlying the above-mentioned cases implicitly. The next section will address that question.

\section{Rethinking EU antitrust law dual federalism beyond delegation}

The above-mentioned overview of cases demonstrates that the traditional 'delegation'-'exclusive competence' principles no longer seem to fit fully the operations of the EU antitrust enforcement system. In fact, the Court of Justice rather seems to presume the existence of pre-emption principles underlying and governing the relationship between EU institutions and national authorities in the application of EU antitrust law. As a result, questions can be raised regarding the existence and applicability of such principles in EU law in general.

This section argues that such principles do indeed exist and are applicable to EU antitrust enforcement (3.1). Such a finding confirms the argument made in other fields of EU law that the European Union is indeed moving from a dual federalism to a more cooperatively structured federal-like entity. Acknowledging this 'cooperative federalism' reality within the field of EU antitrust enforcement raises questions on the need for more explicit constitutional recognition of pre-emption strategies inherent in EU law that could apply in this domain. Building on that need, the final part of this section offers some antitrust-specific suggestions for bringing the dual federalism framework on a par with shared enforcement realities (3.2). 


\subsection{From delegation to pre-emption in EU antitrust enforcement}

The case law examples outlined in the previous section seem to reflect principles regarding the pre-emption of regulatory powers prevailing in EU shared competences (3.1.1). It will be submitted that the two types of pre-emption types generally considered to apply in European Union law can indeed effectively be found underlying this case law (3.1.2).

\subsubsection{Pre-emption as a technique underlying EU shared competences}

Traditionally, a federally structured system of shared regulatory competences presupposes a constitutional set of conflict rules capable of addressing potential conflicts between multiple governance levels. ${ }^{76}$ Principles of federal supremacy and pre-emption have traditionally sought to avert these conflicts. ${ }^{77}$ The EU's constitutional system poses no exception in that regard. The Court of Justice accepted that EU law cannot only produce direct effect in national legal orders, ${ }^{78}$ but that direct effect also implies the primacy of EU law over national law in the case of conflicts between a supranational and a national norm. ${ }^{79}$ In a system of shared competences, the emphasis on primacy also almost naturally implies a principle of federal pre-emption. ${ }^{80}$ Pre-emption in that understanding encompasses a set of principles determining to what extent ${ }^{81}$ national law can be set aside when supranational legislation is enacted. ${ }^{82}$

Although pre-emption is at the heart of EU legal integration, EU law is not governed by a singular or clearly structured pre-emption doctrine.

\footnotetext{
76 On that issue, see Gerald Conway, 'Conflicts of Competence Norms in EU Law and the Legal Reasoning of the ECJ' (2010) 11 German Law Journal 967.

77 Schütze refers to supremacy and pre-emption. See Robert Schütze, 'Supremacy without Pre-emption? The Very Slowly Emergent Doctrine of Community Pre-emption' (2006) 43 CML Rev 1023, 1024. The principle of sincere cooperation ensures a similar connection in an ever more integrated institutional realm and therefore could serve as both a regulative principle determining the extent of competence division from an institutional deliberation perspective as well as an operational principle governing its exercise. See Lawrence Gormley, 'Some Further Reflections on the Development of General Principles of Law within Article 10 EC' in Ulf Bernitz, Joachim Nergelius and Cecelia Gardner (eds), General Principles of EC Law in a Process of Development (Kluwer 2008) 310.

78 Case 26/62 Van Gend \& Loos [1963] ECR 3 (English Special Edition, 1).

79 Case 6/64 Costa Enel [1964] ECR 585; Case 11/70, Internationale Handelsgesellschaft $m b H$ [1970] ECR 1125.

80 For an introductory overview of pre-emption as a principle of federal law in the US, see Mark D Rosen, 'Contextualizing Preemption' (2008) 102 Northwestern University Law Review 781. See also Daniel Farber, 'Federal Preemption of State Law: The Current State of Play' UC Berkeley Public Law Research Paper No. 1740043 <http:/ / papers.ssrn.com/sol3/ papers.cfm?abstract_id=1740043\&rec $=1 \&$ srcabs $=1778363>$ accessed 24 May 2016.

81 Schütze (n 77) 1039. See also António Goucha Soares, 'Pre-Emption, Conflicts of Power and Subsidiarity' (1998) 23 EL Rev 132; Daniel Cross, 'Pre-Emption of Member State Law in the European Economic Community. A Framework for Analysis (1992) 29 CML Rev 447.

82 Schütze (n 77) 1033.
} 
On the contrary, three types of pre-emption can simultaneously be identified within EU law. The actual conditions governing their applicability and scope appear to differ from EU policy field to policy field. ${ }^{83}$ It follows that different pre-emption strategies can accompany specific secondary legislation initiatives or the pragmatic interpretation of certain legal bases included in the Treaties. ${ }^{84}$ In his work on pre-emption, Schütze distinguished between three typologies of pre-emption in that regard: field pre-emption, rule pre-emption and obstacle pre-emption.

Field pre-emption refers to an explicit veto by a federal legislative or regulatory body for States to enact norms in a given policy field. By virtue of legislative or regulatory action taken in a field, supranational or federal law is considered to have a jurisdictional monopoly to the detriment of federated entities, irrespective of whether these entities' norms directly conflict with the enacted supranational rules. ${ }^{85}$ Field pre-emption technically establishes exclusive competences at the supranational or federal level. As a result, field pre-emption results in a sphere of exclusivity being created. It would not be entirely unimaginable that within such a sphere of exclusivity, the supranational level would again delegate some powers to the Member States, which would then be considered as agents of the supranational level. ${ }^{86}$

Rule pre-emption on the other hand takes the existence of shared competences as its starting point. ${ }^{87}$ Although jurisdiction remains shared, rule pre-emption presupposes national rules will be trumped by directly conflicting supranational rules. ${ }^{88}$ From that perspective, the determination of 'direct conflicts' will be crucial to determine the regulatory scope granted to both supranational and national rules. ${ }^{89}$ The Court of Justice, relying on the principle of supremacy, determines the existence of such conflicts and offers the remedy of non-application of conflicting Member State law provisions in this particular situation. ${ }^{90}$

\footnotetext{
83 On that argument, see Schütze (n 9) 187.

84 For that pragmatic view, see also Joseph Weiler, 'The Community System: The Dual Character of Supranationalism' (1981) 1 YEL 267, 295.

85 Schütze (n 77) 1035.

86 As art 2(1) TFEU itself makes clear in its definition of exclusive competences.

87 Konstadinides refers to this kind of pre-emption as implied pre-emption always solved in favour of EU law, at least in the absence of clarifying secondary Union legislation, see Theodore Konstadinides, Division of Powers in European Union Law. The Delimitation of Internal Competence between the EU and the Member States (Kluwer 2009) 170.

88 Schütze (n 77) 1037.

89 For the nascence of the pragmatic framework in that regard, see Weiler (n 84) 278.

90 For examples in this regard, Case 106/77 Amministrazione delle Finanze dello Stato $v$ Simmenthal SpA [1978] ECR 629; Case 102/79 Commission v Belgium [1980] ECR 1487, para 15; Case 149/79 Commission v Belgium [1980] ECR 3903, para 19; Case C-473/93 Commission v Luxemburg 1996 ECR I-3255, para 26; Case C-285/98 Tanja Kreil v Bundesrepublik Deutschland [2000] ECR I-105, para 23; Case C-119/05 Ministero dell'Industria,
} 
Obstacle pre-emption allows supranational law to strike down national rules that constitute obstacles to the objectives to be realised by the supranational level. Stated otherwise, this doctrine allows Member States to continue adopting rules, but only to the extent that they do not impede the full effectiveness of supranational rules. National law could in that regard be pre-empted even when these national rules do not directly conflict with, but merely impose obstacles on, the implementation of supranational provisions. ${ }^{91}$ According to this doctrine, the Court of Justice has to determine, in more or less general or specific terms, the existence of the conditions which have to be fulfilled for such an indirect conflict to be in place. ${ }^{92}$

\subsubsection{Pre-emption in the Court's antitrust enforcement case law}

These three types have, above all, been identified throughout EU shared competences frameworks. ${ }^{93}$ The lack of a general pre-emption framework and the pragmatic application of pre-emption strategies in the European Union at the same time hint at the existence of constitutionally fluid boundaries between exclusive and shared competences. To the extent that the European Union accepts field pre-emption to take place in certain policy areas, competences can shift from the shared to the de facto exclusive sphere of EU competences. Applying this pragmatic understanding of pre-emption strategies to the realm of EU exclusive competences, no EU constitutional provision would seem to impede the inverse operation from EU exclusive competences to de facto shared competences. This is all the more so regarding the implementation and application of EU law in Member States' legal orders, where the EU consistently relies on Member States administrations to enforce European Union law. As more enforcement powers are being 'delegated' within the realm of EU exclusive competences, pre-emption principles generally underlying shared competences can implicitly enter the realm of EU competence demarcation debates. The Court's case law on the application of articles 101 and 102 TFEU by national competition authorities and courts precisely demonstrates this option. It should nevertheless be clear at the outset that, just as in its case law on shared competences, ${ }^{94}$ the Court

del Commercio e dell'Artigianato v Lucchini SpA, formerly Lucchini Siderurgica SpA [2007] ECR I-6199.

91 See Schütze (n 77) 1036.

92 The Court does not always refer to pre-emption in this regard; nevertheless, the principle of effectiveness in relation to national procedural rules constitutes a good example in this respect. See Pieter Van Cleynenbreugel, 'Procedural Autonomy as Integration-reinforcement: The Court of Justice of the European Union and National Procedural Choices' in Wouter Werner and Lukasz Gruszczynki (eds), Standards of Review in International Courts and Tribunals (OUP 2014) 175.

93 Schütze (n 77) 1040.

94 See on that argument Schütze (n 77) 1038. 
does not explicitly refer to doctrines of pre-emption. The techniques applied by it do however resemble or approach some of the pre-emption categories defined by the literature and outlined in the previous section.

The most obvious example of pre-emption-like principles being applicable relates to the case law on antitrust enforcement procedures in the absence of harmonisation measures. Vebic and Eturas clearly indicate that Member States remain free to establish institutional structures and procedural rules enabling EU antitrust enforcement, as long as those national rules do not conflict indirectly with the goals of EU antitrust enforcement set at the supranational level. In case of a conflict with those goals (non-participation of the authority in proceedings against its own decisions or the applicability of rules governing standard of proof that do not enable an infringement of articles 101 and 102 to be effectively proven), Member States will be pre-empted from keeping those rules in place. The existence and avoidance of such conflicts depends entirely on the Court finding them and on it requesting the Member States to address them in particular situations. From the point of view of predictability, Member States have no certainty as to whether such an indirect obstacle with vague and likely modifiable goals of EU antitrust enforcement will have to be remedied. EU antitrust literature shows that the goals of EU antitrust law in general, as well as the goals of EU antitrust enforcement in particular, are subjected to highly diverging interpretations. ${ }^{95}$ In acting so and in implicitly identifying conflicts between EU policy goals and Member State rules, the Court firmly applies techniques that can be classified as obstacle pre-emption techniques. In this understanding, obstacle pre-emption offers the Court of Justice a competence division technique, allowing EU law to intervene in and address some choices made at the Member State level that seem to conflict with evolving EU goals.

The Pfleiderer and Donau Chemie judgments confirm the obstacle pre-emption approach taken in the context of the absence of procedural harmonisation, but also reflect the limited scope of this approach once harmonisation takes place. In projecting a balancing approach regarding access to documents relevant in a private damages action, the Court considered Member States' legislation impeding such a balance to be an obstacle to the realisation of one of the EU antitrust enforcement goals.

\footnotetext{
95 For an overview of debates in this regard, see Rein Wesseling, The Modernisation of EC Antitrust Law (Hart 2000) 80-83; Laura Parret, 'Shouldn't We Know What We are Protecting? Yes We Should! A Plea for a Solid and Comprehensive Debate about the Objectives of EU Competition Law and Policy' (2010) 6 European Competition Journal 339; Pinar Akman, 'Consumer Welfare and Article 82 EC: Practice and Rhetoric' (2009) 32 World Competition 71; Barbara Jedličková, 'One Among Many or One Above All? The Role of Consumers and Their Welfare in Competition Law' (2012) 33 ECLR 568. For a different opinion, see Renato Nazzini, The Foundations of European Union Competition Law. The Objective and Principles of Article 102 (OUP 2012).
} 
Such an approach only holds in the absence of supranational rules which strike a more specific balance themselves. The adoption of Directive 2014/104/EU on damages actions and the clear prohibition to grant access to certain types of documents included therein will limit the scope of balancing to be conducted. In doing so, it will change the parameters within which obstacle pre-emption identified in both judgments will take place. In so stating, the Directive confirms a delegation of some balancing powers to national judges in individual damages actions. This shows that obstacle pre-emption techniques employed by the Court serve as a precursor to govern the exclusive EU antitrust enforcement field in the absence of more specific procedural harmonisation initiatives. Once secondary legislation imposes boundaries on Member States' actors' competences, the latter will have to operate within the confines set by that legislation, limiting the scope of obstacle pre-emption.

To the extent that secondary legislation has already set the parameters, the case law still hints at some kind of pre-emption coming into play. According to the Court's case law in Expedia, Allianz Hungaria and Maxima Latvija, Member States remain free to assess and apply opentextured EU legal norms to specific factual circumstances in the absence of a previously issued binding decision by the Commission or the Court of Justice in the same or a similar case. In its case law, the Court has given some interpretative room to Member States by excluding soft law from the scope of binding EU law decisions. The fact that Member States are obliged, as a matter of article 3 of Regulation 1/2003, to apply articles 101 and 102 TFEU in full means that they have been delegated some interpretative autonomy in doing so. In the exercise of such delegated powers, Member States can interpret articles 101 and 102 TFEU autonomously in the absence of a directly conflicting interpretative decision. Such a decision would create a supranational rule that effectively restrains the interpretative autonomy that Regulation 1/2003 in principle grants to Member States' authorities and courts.

That competence division system resembles the rule pre-emption features identified above in relation to shared competences. The existence of a 'direct conflict' triggering the pre-emption of Member States' interpretative freedom depends on the existence of Commission decisions or CJEU judgments having previously interpreted articles 101 or 102 TFEU regarding the same or a similar set of facts. As a result, such rule preemption is embedded within the delegation framework and conditional on the absence of an EU decision. As such, the Court truly presupposes a pre-emption approach, but only in the absence of specific interpretative guidance granted by the EU institutions. One could therefore say that the Regulation 1/2003 system is built on a framework of rule-interpretation pre-emption. This demonstrates that the powers delegated to Member 
States are rather fluid and depend on the EU institutions having adopted binding decisions; this seems to be the application of the very pre-emption techniques that underlie shared competences.

Although the Court does not recognise it explicitly, both strands of case law demonstrate that some kind of pre-emption techniques support the system set out by Regulation 1/2003. The Court embeds such techniques firmly within a domain of exclusive competence, by virtue of EU secondary legislation granting or delegating powers to the Member State level. This again demonstrates the fluidity between categories of exclusive and shared competences. The EU's particular system of 'cooperative federalism' does not seem to tolerate a rigid division between exclusive and shared competences; ${ }^{96}$ the applicability, albeit implicitly, of shared competences pre-emption techniques within an exclusive competence domain in essence confirms that position in relation to EU antitrust enforcement.

\subsection{Embedding pre-emption techniques in EU exclusive competences?}

To the extent that obstacle and rule(-interpretation) pre-emption techniques indeed implicitly underlie the Court's antitrust enforcement case law, questions can be raised genuinely about the need to recognise the presence of such techniques in the realm of exclusive EU antitrust competences more explicitly as a matter of EU constitutional law. More generally, explicit recognition of such pre-emption techniques within a domain of EU exclusive competences may offer better insights in what it still means to have an exclusive competence in today's European Union. Explicitly integrating pre-emption principles in the realm of exclusive competences may not only benefit the coherence and predictability of EU antitrust enforcement.

The current implicit references to pre-emption in the Court's antitrust enforcement case law and the uncertainties surrounding it support the belief that a more explicit recognition may be useful in order better to understand the roles of different actors within the realm of exclusive EU competences. An explicit recognition would not only guarantee a clearer and more predictable delineation of EU and Member States' competences in the enforcement of EU antitrust law, but would also give both supranational and Member States' authorities and jurisdictions tools to better determine their own roles within the EU's antitrust enforcement system.

With a view to promoting a more explicit recognition of pre-emption possibilities, four legal policy strategies can be envisioned. It can be questioned legitimately whether and to what extent the four proposed legal policy solutions would have any practical value to the application and

96 Schütze (n 9) 188. 
interpretation of EU law. Given the lack of clarity on the scope and even necessity of a pre-emption doctrine in EU law in general, the proposals above all aim to clarify and better tailor EU enforcement realities to the principles underlying the EU's core constitutional features. Above and beyond the more explicit recognition of EU pre-emption realities and the increase in legal certainty flowing therefrom, it could be argued that their practical value would be limited indeed. At the same time, however, the four strategies offered here would allow more direct and focused reflection, from practical realities upwards, on the existence, scope and limits of pre-emption in EU antitrust enforcement and EU law more generally. As such, they would at least open up debates - which can be continued before and resolved by the EU Courts in litigation settings - on how to ensure an appropriate application of the EU's competence principles.

Firstly, the existence of pre-emption as a principle governing the exercise of 'delegated' exclusive competences could be recognised directly within the Treaty framework itself. Pre-emption does not feature in the Treaty framework and has only been identified implicitly in the Court's case law. ${ }^{97}$ An adaptation of the Treaties appears to be, from the point of view of predictability and legal certainty, the most appropriate format to ensure the constitutionality of pre-emption as applied within the realm of EU exclusive antitrust competences. The feasibility of this solution can nevertheless be questioned rightfully, as the scope of pre-emption doctrines and techniques lacks any explicit recognition in the field of shared competences as well. ${ }^{98}$ Given that shared competences are the natural territory for pre-emption techniques and given that any reference to them is lacking in the Treaty provisions on shared competences, it would be rather strange to include an explicit reference to them in relation to exclusive competences in the absence of a fuller recognition of pre-emption as a principle also underlying shared competences.

Secondly, the Court of Justice could develop a more explicit preemption theory, resulting in a few clear-cut guidelines for national actors on how to deal with situations that potentially conflict with EU antitrust law. In doing so, a doctrine comparable to the primacy/supremacy doctrine could be more explicitly developed. As has been remarked on numerous occasions, however, the Court has so far refrained from doing this in the realm of shared competences. It would seem unlikely that the specific situation of EU antitrust enforcement would be taken as a starting point more fully to develop this doctrine as a matter of EU constitutional law. In addition, it can also be argued that it is not the Court's

97 See the pioneering work of Michel Waelbroeck, 'The Emergent Doctrine of Community Pre-emption: Consent and Redelegation' in Eric Stein and Terrance Sandalow (eds), Courts and Free Markets: Perspectives from the United States and Europe (Clarendon 1982) 458.

98 As Schütze confirmed recently; see Schütze (n 77) 1032. 
role to develop general theories of pre-emption, but rather to apply and interpret EU law in particular circumstances.

Thirdly, a related alternative solution could consist in interpreting the principle of sincere cooperation more explicitly as containing a bundle of pre-emption techniques. Sincere cooperation presupposes that both the federal or supranational level and the federated levels engage in cooperation and consultations with a view to allowing a workable division of competences to emerge from regulatory practice. The principle of sincere cooperation serves as a constitutional catch-all provision governing mutual duties and obligations between the national and supranational levels. ${ }^{99}$ It is also the foremost constitutional expression of cooperative federalism. ${ }^{100}$ In accordance with the principle of sincere cooperation outlined in article 4(3) TEU, both supranational and national authorities are called upon to assist each other in fulfilling the tasks which flow from the Treaties. Member States shall in particular assist the Union and refrain from any action or inaction that could jeopardise the Union's actions.

The Court of Justice held in Zwartveld that Union institutions are also bound sincerely to cooperate with national courts regarding the provision of information in competition law matters. ${ }^{101}$ An extrapolation of that judgment, in conjunction with article 12 of Regulation 1/2003 could be read as a duty imposed on the Commission to share particular documents with Member States' authorities as well. In the interest of sincere cooperation between different governance levels enjoying parallel competences, it could therefore also be argued that clear pre-emption principles and limits would serve to enable sincere cooperation truly to take shape in the specific EU antitrust enforcement framework. It would therefore not be entirely impossible that the Court relies on the principles of sincere cooperation to clarify and limit the scope of permissible pre-emption within the domain of EU antitrust enforcement. Given the very openended nature of that principle, such inclusion would not seem to be impossible constitutionally, granted that the Court would be willing indeed to take this step. Recent case law does not seem to show a willingness to invoke this principle. It could nevertheless be considered a viable way forward at a time when the acknowledgment of more explicit pre-emption principles would be considered more necessary.

Fourthly, the most appropriate solution therefore seems to be a more explicit direct recognition of pre-emption principles or techniques

\footnotetext{
99 On the principle's operation in that regard, see John Temple Lang, 'The Development by the Court of Justice of the Duties of Cooperation of National Authorities and Community Institutions under Article 10 EC' (2007-2008) 31 Fordham International Law Journal 1483. ${ }^{100}$ Robert Schütze, 'From Rome to Lisbon: "Executive federalism” in the (New) European Union' (2010) 47 CML Rev 1385, 1398.

${ }^{101}$ See Case C-2/88 Zwartveld [1990] ECR I-3365, para 17.
} 
in instruments of secondary legislation. As Regulation 1/2003 in this respect contains specific conflict rules regarding the interaction and parallel application of EU and national competition law, it would not seem unimagineable to include similar rules governing the interpretation of openended Treaty antitrust provisions by national authorities and courts in the absence of a binding decision incorporating a specific interpretation in the same or similar cases. As others have proposed to revise Regulation $1 / 2003$ on other points, ${ }^{102}$ it can be submitted that a more explicit recognition of rule-interpretation pre-emption principles presents a feasible solution. If that solution were opted for, a clear-cut rule should be inserted in the Regulation.

A proposed provision to that extent could be phrased as follows:

1. National competition authorities will apply articles 101 and/ or 102 TFEU within the boundaries set by the Court of Justice of the European Union, this Regulation and other binding instruments of secondary legislation. In the absence of relevant precedent decisions, national authorities and courts can interpret articles 101 and/or 102 TFEU in accordance with their meaning and content. This provision does not impede requests for opinions to or interventions from the European Commission in particular cases, in accordance with other provisions of this Regulation. 2. In the absence of specific procedural requirements imposed by this Regulation or any other instrument of EU law, Member States are responsible to organise their institutional frameworks and procedures so as to accommodate EU law claims. National choices made in this regard cannot constitute obstacles to the realisation of EU antitrust enforcement goals as outlined in this Regulation. ${ }^{103}$

Whilst it may appear that this provision restates the obvious in the wake of the Court's judgments in Expedia, Allianz Hungaria and Maxima Latvija, the addition of this principle clearly as a matter of EU secondary legislation would empower Member States' authorities and courts more directly whenever they want to apply articles 101 and 102 TFEU in compliance with the enforcement system set up by Regulation 1/2003, but

\footnotetext{
${ }^{102}$ Wouter Wils, 'Ten Years of Regulation 1/2003 - A Retrospective' (2013) 4(4) Journal of European Competition Law \& Practice 293.

103 To the extent that a provision of this kind would be inserted in Regulation 1/2003, the EU institutions could equally hold that Commission guidance documents would be binding on national authorities. Such acknowledgment would nevertheless trigger new questions on the invocability and binding nature of EU soft law, which would go beyond the confines of this contribution. On those problems in a different context, see, recently, Merijn Chamon, 'Le recours à la soft law comme moyen d'éluder les obstacles au développement des agences de l'UE' (2014) Revue de l'Union européenne 152.
} 
in the absence of a binding EU precedent in the specific factual setting. As such, it would above all provide more legal certainty than is the case today. Such a provision would additionally also enable the Court more explicitly and comfortably to set the legal boundaries of the pre-emption approach when being asked to do so in the context of a specific case situation.

The inclusion of this provision in the Regulation would at the same time seem to presuppose that clarity exists on the goals of EU antitrust enforcement. As mentioned earlier, those goals are embedded more generally in discussions about the goals of EU competition law. Those goals tend to be rather fluid and shifting over time. Even the insertion of a provision such as the one proposed could not impede a Member State rule considered to be compatible with EU law today from being deemed an obstacle against the background of shifting antitrust enforcement goals. At the same time, the recognition of pre-emption techniques at the very least would make it clearer that Member States do retain their proper regulatory and interpretation powers, even against a background of changing enforcement goals.

\section{Conclusion}

The EU system of competence conferral remains rather fluid, despite different categories of competences now being recognised explicitly in the TFEU. This paper has highlighted that this fluidity may have an impact on the way in which EU law principles traditionally limited to shared competences can also come into play as meaningful constitutional benchmarks in the assessment and interpretation of EU exclusive competences. To that extent, the paper has analysed the ways in which EU antitrust enforcement mechanisms have been given shape.

The establishment of competition rules falls within the exclusive competences of the European Union. As a result, EU institutions are in principle responsible for the determination and application of EU competition law rules. Member States will only be competent in competition law matters outside the realm of $E U$ competition law or to the extent that EU institutions have delegated certain competences or powers to Member States' actors. In the realm of EU antitrust enforcement, Regulation $1 / 2003$ and the supporting mechanisms enabling the decentralised enforcement of articles 101 and 102 TFEU at first sight clearly confirm this delegation approach. In doing so, the Court of Justice confirms that EU competences cannot be captured in clear categories of exclusive, shared or complementary competences each governed by their own constitutional logic. 
To that extent, this contribution has explored the EU law possibilities for a more explicit recognition of the applicability of pre-emption techniques in the realm of EU exclusive antitrust competences and beyond. On a practical level, whereas the explicit recognition of pre-emption within the Treaty framework or by the Court appears to be a desirable option, it was submitted that the acknowledgment of such techniques more explicitly within a delegating instrument such as Regulation 1/2003 would be a first step in the right direction. On a more theoretical level, the conceptualisation of a competence as exclusive clouds the understanding of the Member States' necessary role in the administration and enforcement of EU exclusive competences. The contribution has therefore also proposed a more tailored interpretation of the principle of sincere cooperation in the context of EU exclusive competences as a means to bring pre-emption or pre-emption like techniques firmly within the ambit of those competences and remaining within the current constitutional settlement reflected in the founding Treaties. 